\begin{tabular}{ll}
\hline & $\begin{array}{l}\text { International Journal of Health Services Research and Policy } \\
(2019) 4(1): 1-10\end{array}$ \\
& Published online April, 2019 (http://dergipark.gov.tr/ijhsrp) \\
doi: $10.23884 /$ ijhsrp.2019.4.1.01 \\
INESEG & e-ISSN: 2602-3482 \\
ENGINEERING, & Received: December 13, 2018 Accepted: March 12, 2019 \\
SCIENCE AND & Submission Type: Research Article \\
EDUCATION GROUP &
\end{tabular}

\title{
HEALTHY LIFESTYLE BEHAVIORS OF STUDENTS AT THE FACULTY OF EDUCATION
}

\author{
Elif IŞIK ${ }^{*}$, Yalçın KANBAY ${ }^{1}$, Özgür ASLAN ${ }^{1}$ \\ ORCID: 0000-0001-7071-7654; ORCID: 0000-0002-8025-9877; ORCID: 0000-0001-8817-4299 \\ ${ }^{1}$ Artvin Coruh University, Faculty of Health Sciences \\ *Corresponding author; elifsyo@gmail.com
}

\begin{abstract}
This study was conducted for the purpose of evaluating the healthy lifestyle behaviors of students at the Faculty of Education. The study sample consisted of 300 students who receive education at the faculty of education. The "Socio-demographic features form" and "Healthy Lifestyle Behavior Scale II (HLBS)" were used in the data collection stage of the study. The data were analyzed in the SPSS 23 environment using number, mean, percentage, analysis of variance, $t$-test, and correlation analysis. The Kruskal-Wallis and Mann-Whitney U tests were used as nonparametric tests. In order for the study to be carried out, the ethics committee approval from Artvin Çoruh University Ethics Committee, written permission from the institution where the study was conducted, and verbal approval from the participants were obtained. According to the findings of the study, the students' point average for the HLBS was determined as $124.86 \pm 1.092$ points. The healthy lifestyle behaviors of students do not differ according to gender, family type, class, smoking, alcohol use and the presence of a chronic illness. However, as the number of individuals and siblings in the family increases, the healthy lifestyle behaviors of students decrease, and as the educational level of the mother and the economic level increase, the healthy lifestyle behaviors also increase. On the other hand, the educational level of the father is not related to the healthy lifestyle behaviors of students. In the light of the results of the study, it is suggested to carry out comparative studies with wider samples that examine the healthy lifestyle behaviors of students.
\end{abstract}

Key words: Healthy life behaviors, faculty of education students, health promotion.

Note: This study was presented as an oral presentation at the International Artvin Symposium on October 18-20, 2018. 


\section{Introduction}

As defined by World Health Organization, health is a "state of complete physical, mental, and social well-being, and not merely the absence of disease or infirmity." However, if we make a functional definition of health rather than consider it as an abstract concept, we can define it as an essential state and right of people to lead individually, socially and financially efficient lives [1]. Being healthy is actually to upgrade the current well-being, which is only possible through maintenance and improvement of health [2]. Basic concepts in health maintenance and improvement are the change of behaviors and lifestyles [3]. The change of behaviors and lifestyles begins with the awareness and knowledge of individuals about their responsibilities regarding their own health and is learned and improved with health education [2]. Health education is one of the methods for teaching and reinforcing healthy lifestyle behaviors through behavior change in maintenance and improvement of health [3]. Healthy lifestyle behaviors (HLB) are defined as "behaviors that help individuals maintain and improve their own well-being". Healthy lifestyle behaviors are not only behaviors that prevent people from developing a disease and support them to be more healthy, but are also behaviors that improve their health/well-being throughout their lives $[4,1]$. Healthy lifestyle behaviors include sufficient and balanced nutrition, stress management, regular exercises, moral development, interpersonal relationships and taking responsibility regarding maintenance and improvement of health [5]. Adoption of healthy lifestyle behaviors is possible through the change of knowledge, thoughts and values of individuals. Therefore, health education must be given due consideration. Teachers who have significant roles in children's education set an example with their professional responsibilities, social roles and lifestyles, have an influence on students with the education they provide and are role models for them [6]. Teachers are expected to possess adequate knowledge and practice with regard to health promoting behaviors, because an educator who does not care about his/her own health is not expected to care about other people's health and influence others thereon [7].

University life is a period when important changes occur in the lives of individuals. University education results in changes not only in vocational training but also in personality development, personal life and health behaviors. These changes are specifically important in terms of attitudes and behaviors in healthcare, because attitudes and behaviors of students regarding healthcare affect both themselves and their families and society. Health status of populations is measured by the majority of healthy individuals within the society $[8,9]$. Healthy Introduction and practice of healthy lifestyle behaviors during university education significantly affects the attitudes and behaviors of teacher candidates in the future [9].

The students of faculty of education, in particular, are known to be influential in improving students' health when they start working as teachers. Also, the determination of good and poor health behaviors of students not studying in a health-related department may be helpful in development and implementation of curricula. This study was conducted to determine the healthy lifestyle behaviors of students of faculty of education and the factors affecting such behaviors.

\section{Material and Method}

2.1. Study Design: The study was designed as a descriptive study.

2.2. Study Location and Time: The study was conducted in 2017-2018 academic year in the Faculty of Education of Artvin Coruh University.

2.3. Study Universe and Study Sample: The study universe consisted of 1003 students of the Faculty of Education. The sample size calculation formula $\left(\mathrm{Nt}^{2} \mathrm{pq} / \mathrm{d}^{2}(\mathrm{~N}-1)+\mathrm{t}^{2} \mathrm{pq}\right)$ was used to determine the 
sample size of the study [10]. According to the calculation, the minimum sample size to be selected was determined as 278 in a universe of 1003 individuals with 5\% error margin and 95\% confidence. However, since this is the minimum value, a higher number of students were selected and 318 students were included in the study. Since some students failed to answer all questions in the questionnaire, the study sample consisted of 300 students.

2.4. Data Collection: Study data were collected by lecturers known by the students but otherwise irrelevant to the study to avoid bias toward the study. After the aforementioned lecturers were informed on the study content and questionnaires, data collection process started. Average time to fill questionnaires was determined as 5 minutes.

2.5. Data Collection Tools: For data collection, "Socio-demographic characteristics form" and "Healthy Lifestyle Behaviors Scale II (HLBS)" were used.

2.5.1. Socio-Demographic Characteristics Form: It is a form to inquire about socio-demographic characteristics of participants.

\subsubsection{Healthy Lifestyle Behaviors Scale II (HLBS):}

The scale was developed by Walker et al. (1987) and revised in 1996 (Walker et al., 1996). It measures health promoting behaviors of individuals in association with their healthy lifestyle [11, 12]The scale consists of a total of 52 positive items and has 6 subscales. The subscales include moral development, health responsibility, physical activity, nutrition, interpersonal relationships and stress management. The overall score received from the scale is the healthy lifestyle behaviors score. The rating scale is 4-point Likert type. The responses are never (1), sometimes (2), often (3), regularly (4). The lowest score for the entire scale is 52 , while the highest score is 208 . Turkish validity and reliability studies of the scale were conducted by Bahar et al. (2008) and its Alpha reliability coefficient is 0.92. In the present study, Alpha reliability coefficient is determined as 0.91 [13].

2.6. Data Assessment: Data were assessed in SPSS 18.0 software. Number, mean and percentage values were used for descriptive data. Variance analysis and t-test were used as parametric test and Kruskal Wallis and Mann-Whitney $U$ tests were used as non-parametric test for the detection of differences and Correlation analysis was used for the detection of relationships.

2.7. Ethical Aspects of the Study: For this study, the approval of Artvin Coruh University Ethical Committee, a written permission from the institution where the study was conducted and the verbal consent of participants were provided. 


\section{Findings}

Table 1. Averages of students' HLBS II and scale sub-dimensions

\begin{tabular}{|c|c|c|c|c|c|}
\hline Scale and scale sub-dimensions & $\mathbf{n}$ & Min & Max & Average & Ss \\
\hline Health responsibility sub-dimension & & 9 & 32 & 19.82 & .254 \\
\hline Physical activity sub-dimension & & 8 & 32 & 16.44 & .287 \\
\hline Nutrition sub-dimension & & 9 & 32 & 19.66 & .236 \\
\hline $\begin{array}{l}\text { Sub-dimension of spiritual } \\
\text { development }\end{array}$ & 300 & 14 & 35 & 25.24 & .257 \\
\hline $\begin{array}{l}\text { Interpersonal relationships sub- } \\
\text { dimension }\end{array}$ & & 12 & 35 & 24.74 & .257 \\
\hline Stress management sub-dimension & & 11 & 32 & 18.95 & .206 \\
\hline HLBS II & & 78 & 183 & 124.86 & 1.092 \\
\hline
\end{tabular}

HLBS "health responsibility subscale" mean score of students was $19.82 \pm .254$, "physical activity subscale" mean score was $16.44 \pm .287$. "Nutrition subscale" mean score was $19.66 \pm .236$, "moral development subscale" mean score was $25.24 \pm .257$, "interpersonal relationships subscale" mean score was $24.74 \pm .257$ and "stress management subscale" mean score was $18.95 \pm .206$. Mean HLBS score of students was calculated as $124.86 \pm 1.092$.

Table 2. The averages and differences of HLBS II according to some variables

\begin{tabular}{|c|c|c|c|c|c|c|}
\hline & & $\mathbf{n}$ & $\%$ & $\mathbf{X}$ & Ss & Significance \\
\hline \multirow[t]{2}{*}{ Gender } & Male & 196 & 65.3 & 124.90 & 1.382 & $\mathrm{t}: .052$ \\
\hline & Woman & 104 & 34.7 & 124.79 & 1.777 & $\mathrm{p}>0.05$ \\
\hline \multirow[t]{2}{*}{ Family type } & Core & 219 & 73 & 124.57 & 1.270 & t:-.437 \\
\hline & Broad & 81 & 27 & 125.64 & 2.145 & $\mathrm{p}>0.05$ \\
\hline \multirow[t]{4}{*}{ Class } & 1 & 108 & 36.0 & 125.33 & 1.705 & \\
\hline & 2 & 71 & 23.7 & 126.89 & 2.255 & F:.612 \\
\hline & 3 & 43 & 14.3 & 122.63 & 3.199 & $\mathrm{p}>0.05$ \\
\hline & 4 & 78 & 26.0 & 123.58 & 2.194 & \\
\hline \multirow[t]{3}{*}{ Cigaret } & YeS & 59 & 19.7 & 122.41 & 2.408 & \multirow{3}{*}{$\begin{array}{l}\mathrm{KW}: 1.055 \\
p>005\end{array}$} \\
\hline & No & 218 & 72.7 & 125.65 & 1.281 & \\
\hline & Sometimes & 23 & 7.7 & 123.65 & 4.192 & \\
\hline
\end{tabular}




\begin{tabular}{lllllll} 
Alcohol & Often & 20 & 6.7 & 115.70 & 3.505 & KW:5.153 \\
& No & 256 & 85.3 & 125.90 & 1.197 & $\mathrm{p}>0.05$ \\
& Sometimes & 24 & 8.0 & 121.33 & 3.446 & \\
chronic & Yes & 23 & 7.7 & 123.91 & 3.828 & MW-U:3159 \\
disease & No & 277 & 92.3 & 124.94 & 1.141 & $\mathrm{p}>0.05$ \\
\hline
\end{tabular}

Mean HLBS scores of men were $124.90 \pm 1.382$ and those of women were $124.79 \pm 1.777$, and the difference was found to be statistically insignificant. It is inferred from this finding that there was no difference between men and women in terms of healthy lifestyle behaviors. Participants with elementary families had a mean HLBS score of $124.57 \pm 1.270$ and those with larger extended families had a mean HLBS score of $125.64 \pm 2.145$, and the difference was found to be statistically insignificant. It is inferred from this finding that there was no difference between individuals with elementary family type and extended family type in terms of healthy lifestyle behaviors. Mean HLBS scores of students according to their grades demonstrate that mean scores of students in 1st, 2nd, 3rd and 4th grades are $125.33 \pm 1.705$ points, $126.89 \pm 2.255$ points, $122.63 \pm 3.199$ points and $123.58 \pm 2.194$ points respectively, and these scores were statistically similar. It is concluded from this finding that healthy lifestyle behaviors of students did not differ according to the grade. Regular smokers had a mean HLBS score of $122.41 \pm 2.408$, occasional smokers had a mean score of $123.65 \pm 4.192$ and non-smokers had a mean score of $125.65 \pm 1.281$. Although non-smokers had higher mean HLBS score than occasional smokers, and occasional smokers had higher score than regular smokers, the differences were statistically insignificant. Smoking behaviors of students had no effect on their healthy lifestyle behaviors. Frequent alcohol consumers had a mean HLBS score of $115.70 \pm 3.505$, occasional alcohol consumers had a mean score of $121.33 \pm 3.446$ and non-consumers had a mean score of $125.90 \pm 1.197$, and the difference was found to be statistically insignificant. Alcohol consumption behaviors of students were detected to have no effect on their healthy lifestyle behaviors. Students with chronic diseases had a mean HLBS score of $123.91 \pm 3.828$ while students with no chronic diseases had a mean score of $124.94 \pm 1.141$, and the difference was insignificant. Presence or absence of a chronic condition had no impact on their healthy lifestyle behaviors.

Table 3. The relationship between some demographic characteristics of the students and HLBS II

\begin{tabular}{lllll}
\hline Variable & $\mathbf{n}$ & $\mathbf{r}$ & $\mathbf{r 2}$ & Significance \\
\hline $\begin{array}{l}\text { Number of siblings } \\
\text { Number of individuals in the }\end{array}$ & -.176 & .03 & $\mathrm{p}<0.05$ \\
family & -.155 & .02 & $\mathrm{p}<0.05$ \\
Mother education level & 300 & .123 & .02 & $\mathrm{p}<0.05$ \\
Father education level & & .104 & .01 & $\mathrm{p}>0.05$ \\
Economic level & .201 & .04 & $\mathrm{p}<0.001$ \\
Health perception & .316 & .10 & $\mathrm{p}<0.001$ \\
\hline
\end{tabular}


A negative, low correlation was found between the number of siblings and mean HLBS scores of students. The higher the number of siblings of students were, the fewer healthy lifestyle behaviors the students had. A negative, low correlation was detected between the numbers of family members and mean HLSB scores of students. As the number of students' family members increased, their healthy lifestyle behaviors decreased. A positive, low correlation was found between mothers' educational level and mean HLBS scores of students. As the mothers' educational level increased, healthy lifestyle behaviors of students also increased. Although mothers' educational levels had an effect on healthy lifestyle behaviors of students, no statistically significant correlation was detected between fathers' educational levels and mean HLBS scores of students. A statistically positive, moderate correlation was observed between economic statuses and mean HLBS scores of students. As the economic status of students increased, their healthy lifestyle behaviors also increased. The correlation between the health perception and mean HLBS scores of students was low and positive. As the health perception of students increased, their healthy lifestyle behaviors also increased.

\section{Discussion}

In the present study, healthy lifestyle behaviors of students studying in a faculty of education are investigated. Healthy Lifestyle Behaviors are calculated as health responsibility subscale, physical activity subscale, nutrition subscale, moral development subscale, interpersonal relationships subscale, stress management subscale and HLBS scores. According to the scale, as the scores of students get closer to the upper limit, their healthy lifestyle behaviors increase. The lowest obtainable HLBS score is 52 and the highest score is 208. In this study, HLBS scores of students were 78 at the lowest level, 183 at the highest level and the mean score was $124.86 \pm 1.092$ (Table 1). HLBS scores of students are close to average and similar with the results of studies conducted in other departments of universities $[9,14,15]$. Higher mean scores were obtained in studies with nursing students [16, 17], a study with students in science teaching department [7] and a study with mixed gender group of students [18]. This may be due to the course contents involving health improvement in nursing departments. In a study in Hong Kong, mean HLBS scores were observed to be lower (119.85) compared to our country [19]. Mean scale scores were found to be 125.76 in study conducted in the USA with Japanese students [20]. As evidenced by these studies, mean HLBS score is generally close to average. This may result from the fact that students do not receive adequate training on how to improve and maintain their health or are unable to transfer the theoretical knowledge into practice due to other reasons. Especially since nurses and teachers are role models in terms of healthy behaviors, they may set examples by adopting these behaviors throughout their education.

Subscale scores show that the highest mean scores are in 'moral development (25.24 \pm .257$)$ and interpersonal relationships $24.74 \pm .257$ )' subscales, while the lowest mean scores are in 'physical activity' $(16.44 \pm .287)$ subscale (Table 1$)$. Many studies produced similar results. Karadeniz et al. (2008); Akgün Kostak et al. (2014); Yurdataman et al. (2014) obtained similar results in their respective studies. In a study by Tokuç et al. (2007), moral development and health responsibility subscale scores were found high followed by interpersonal relationship subscale score. In the present study, the highest mean score obtained in moral development and interpersonal support subscales indicates that students build relationships with others by sharing their thoughts and sentiments through verbal and non-verbal messages. High mean scores obtained in these two subscales can be assessed as a positive result for 
teacher candidates in performance of their future professions. Low scores in physical exercise subscale demonstrates that students have not established the positive habit of physical exercise or transferred it into practice.

Mean HLBS scores of students according to some variables show that gender, family structure, grade, smoking/alcohol consumption and presence of a chronic condition had no impact on healthy lifestyle behaviors of students (Table 2). It was observed in other studies that students who stated to have a good perception of health, female students and 3rd-4th grades, had higher and more significant scores than male students and 1st-2nd grades [9, 18, 21, 16, 8].

On the other hand, although the difference was statistically insignificant, non-smokers had higher mean HLBS scores $(125.65 \pm 1.281)$ than occasional smokers $(123.65 \pm 4.192)$, and occasional smokers had higher HLBS scores $(122.41 \pm 2.408)$ than regular smokers. Similarly, frequent alcohol consumers had a mean HLBS score of $115.70 \pm 3.505$, occasional alcohol consumers had a mean score of 121.33 \pm 3.446 and non-consumers had a mean score of $125.90 \pm 1.197$, and the difference was found to be insignificant. Some studies suggest that smoking and alcohol consumption behaviors have no effect on developing healthy lifestyle behaviors [9]. This suggestion may be due to the fact that smoking and alcohol consumption behaviors are infrequent among students. In a similar study, mean scores of nonsmokers were found high and significant compared to other students $[14,7,15]$.

A negative, low correlation was detected between the number of siblings and family members and mean HLBS score of students (Table 3). As the number of siblings and family members of students increased, their healthy lifestyle behaviors decreased. The effect of higher number of family members on mean HLBS score can be explained by economic factors. It is also thought that higher number of family members negatively affect the behavior of taking care of their own health. In a study with adolescents, it was observed that mean HLBS score decreased as the number of siblings increased [22]. As opposed to this finding, it was detected in another study that family size had no impact on HLBS score [23, 22]. In a study with nurses, individuals with large families had higher mean HLBS scores [24]. Similarly, students living with their parents had higher mean HLBS scores [25].

A positive, low correlation was found between mothers' educational levels and mean HLBS scores. As the mothers' educational level increased, healthy lifestyle behaviors of students also increased. Studies are available indicating that mothers' educational level is effective in the development of healthy lifestyle behaviors [8,26]. Mothers with high educational levels are role models for children in terms of taking responsibility of their own health. However, the study did not reveal a statistically significant correlation between fathers' educational level and mean HLBS scores. It is thought that this may be due to the fact that mothers traditionally assume more responsibilities in children's education and health maintenance or acting as role models. There are also studies demonstrating that mother or father's educational status has no effect [9]

A statistically positive, moderate correlation was found between economic status and mean HLBS scores of students (Table 3). As economic status of students improved, their healthy lifestyle behaviors also increased. This is a natural and expected result. In general, individuals with low socioeconomic status are deemed to be disadvantageous in terms of developing healthy behaviors. High economic status is considered to enhance the extent to which individuals adopt healthy behaviors. Economic status are highly effective in terms of developing healthy behaviors, particularly nutrition behaviors. In parallel with this study, similar results were obtained in other studies as well [8, 27, 9, 26] 
A positive, low correlation was detected between health perceptions and mean HLBS scores of students. Healthy lifestyle behaviors of students increased as their positive perception of health increased (Table 3). Numerous studies are in line with this study. It can be said that individuals with good perception of their health are more careful about exhibiting healthy lifestyle behaviors. Studies in the literature also support this study [14, 15].

\section{Results and recommendations}

Mean HLBS score of students was found to be $124.86 \pm 1.092$. No difference was detected between men and women in terms of healthy lifestyle behaviors. Healthy lifestyle behaviors of students did not differ according to family type and grade variables. Although non-smokers had higher mean HLBS score than occasional smokers and occasional smokers had higher mean HLBS score than regular smokers, differences were statistically insignificant. Furthermore, alcohol consumption of students was found to have no effect on healthy lifestyle behaviors. Presence or absence of a chronic condition had no impact on healthy lifestyle behaviors.

A negative, low correlation was found between the number of siblings and family members and mean HLBS scores of students. As the number of siblings and family members of students increased, their healthy lifestyle behaviors decreased. No statistically significant correlation was detected between fathers' educational level and mean HLBS score although healthy lifestyle behaviors of students increased as their mothers' educational level increased. A statistically positive, moderate correlation was detected between mean HLBS scores and economic status of students and a positive, low correlation was detected between health perception and mean HLBS scores of students.

In line with these results, it is recommended to conduct more advanced comparative studies on healthy lifestyle behaviors of students with larger sample sizes.

\section{References:}

[1] Ş. Bahar Özvarış, Săgll̆ğ Geliştirme ve Sağlık Ĕgitimi, Ankara: Hacettepe Üniversitesi Yayınlar1, 2011.

[2] F. Güdücü Tüfekçi, "Sağlığı Koruma ve Geliştirmede Sağlık Eğitiminin Önemi", Sağglı̆̆ Koruma Ve Geliştirme, Ed. B.C. Demirbağ, Göktuğ Yayıncılık, Amasya, 2016.

[3] Z. U. Gökkoca, "Sağlık Eğitimi Açısından Temel İlkeler", Sted, 10(10), 371-374, 2001.

[4] Z. Bahar ve A. Bayık, Sağglı̆ın Geliştirilmesi ve Sağlık Eğitimi, DSÖ: LEMON Hemşirelikte Eğitim Materyali, Bölüm 5,No:605, Ankara: Sağlık Bakanlığı Matbaası, 1998.

[5] N. J. Pender, S. N. Walker ve j. K. Madeleine, "Health Promoting Lifestyle of Older Adults: Comparations With Young and Middle Aged Adults, Correlates and Patterns", Advanced Nursing Science, 11(1), 76-79, 1988.

[6] B. Tokuç ve U. Berberoğlu, "Edirne Merkez İlçe İlköğretim Okullarında Çalışan Öğretmenlerde Sağlığı Geliştirici Davranışlar", TSK Koruyucu Hekimlik Bülteni, 6(6), 421-426, 2007.

[7] M. Yurdatapan, E. Benzer ve İ. Güven, "Fen Bilgisi Öğretmenliği Öğrencilerinin Sağlıklı Yaşam Biçimi Davranışlarının Değerlendirilmesi", Miili Eğitim, 201, 183-201, 2014. 
[8] S. Ayaz, S. Tezcan ve F. Akıncı, "Hemşirelik Yüksekokulu Öğrencilerinin Sağlığı Geliştirme Davranışları", C.Ü.Hemşirelik Yüksek Okulu Dergis, 9(2), 26-34, 2005.

[9] G. Karadeniz, E. Yanıkkerem Uçum, Ö. Dedeli ve Ö. Karaağaç, "Üniversite Öğrencilerinin Sağlıklı Yaşam Biçimi Davranışları", TAF Preventive Medicine Bulletin, 7(6), 497-502, 2008.

[10] T. Baş, Anket, 6. dü., Ankara: Seçkin, 2010.

[11] S. N. Walker, K. R. Sechrist ve N. J. Pender, "The Health Promoting Lifestyle Profile development and psychometric characteristics", Nursing Research, 36(2), 76-80, 1987.

[12] S. N. Walker ve D. M. Hill-Polerecky, "Psychometric evaluation of the Health Promoting Lifestyle Profile II. Unpublished manuscript", University of Nebraska Medical Center, 1996.

[13] Z. Bahar, A. Beşer, N. Gördes ve A. Kıssal, "Sağlıklı Yaşam Biçimi Davranışları Ölçeği II'nin Geçerlik ve Güvenirlik Çalışması", Cumhuriyet Üniversitesi Hemşirelik Yüksekokulu Dergisi, 12(1), 1-13, 2008.

[14] M. Akgün Kostak, S. Kurt, N. Süt , Ö. Akarsu ve G. D. Ergül, "Hemşirelik ve Sınıf Öğretmenliği Öğrencilerinin Sağlıklı Yaşam Biçimi Davranışları", TAF Preventive Medicine Bulletin, 13(3), 189-196, 2014.

[15] H. İskender, E. Dokumacioğlu, Y. Kanbay ve N. Kılıç, "Üniversite Öğrencilerinde Sağlıklı Yaşam ve Depresyon Puan Düzeyleri ile İlgili Faktörlerin Belirlenmesi", ACU Sağlık Bil Derg, 9(4), 414-423, 2018.

[16] T. Aksoy ve H. Uçar, "Hemşirelik Öğrencilerinin sağlıkı Yaşam Biçimi Davranışları", Hacettepe Üniversitesi Hemşirelik Fakültesi Dergisi, 1(2) ,53-67, 2004.

[17] Ş. Ecevit Alpar, L. Şenturan, Ü. Karabacak ve N. Sabuncu, "Change in the health promoting lifestyle behaviour of Turkish University nursing students frombeginning to end of nurse training", Nurse Education in Practice, 8, 382-388, 2008.

[18] A. Çoban, F. Adana, A. Taşpınar ve H. Arslantaş, "Üniversite Öğrencilerine Verilen Sağlığıklı Yaşam biçimi Davranışları DErsinin Etkinliğinin Ölçülmesi", Balıkesir Sağlık Bilimleri Dergisi, 6(1), 16-21, 2017.

[19] R. L. Lee ve A. J. Yuen Loke, "Health-Promoting Behaviors and Psychosocial Well-Being of University Students in Hong Kong", Public Health Nursing, 22(3), 209-220, 2005.

[20] R. S. Hawks, H. N. Madanat, R. M. Merill, M. B. Goundy ve T. A. Miyagwa, "CrossCultural Comparison of Health Promoting Behaviours Among College Students", The Journal of Health Education, 5, 84-92, 2002.

[21] N. G. Ertop, A. Yılmaz ve Y. Erdem, "Üniversite Öğrencilerinin Sağlıklı Yaşam Biçimleri", KÜ Tip Fak Derg, 14(2), 1-7, 2012.

[22] M. Karadamar, R. Yiğit ve M. A. Sungur, "Ergenlerin Sağlıklı Yaşam Biçimi Davranışlarının Değerlendirilmesi", Anadolu Hemşirelik ve Sağlık Bilimleri Dergisi, 17(3), 131-139, 2014. 
[23] G. Oyur Çelik, A. T. Malak, M. Bektaş, D. Yılmaz, A. Sami Yümer, Z. Öztürk ve E. Demir, "Sağlık Yüksekokulu Öğrencilerinin Sağlığı Geliştirme Davranışlarını Etkileyen Etmenlerin İncelenmesi", Anatol J Clin Investig, 3(3), 164-169, 2009.

[24] S. Özkan ve E. Yılmaz, "Hastanede Çalışan Hemşirelerin Sağlıklı Yaşam Biçimi Davranışları", Fırat Sağlık Hizmetleri Dergisi, 3(7), 89-105, 2008.

[25] E. Yılmaz ve S. Özkan, "Üniversite Öğrencilerinin Beslenme Alışkanlıklarının İncelenmesi", Firat Sağlık Hizmetleri Dergisi, 2(6), 87-104, 2007.

[26] Ö. Köseoğlu Örnek ve A. Kürklü, "Üniversite Öğrencilerinin Sağlıklı Yaşam Biçimi Davranışlanı, Öz Etkililik-Yeterlilik Düzeyleri ve Etkileyen Faktörler", Turkiye Klinikleri J Nurs Sci, 9(3), 207-217, 2017.

[27] N. İlhan, M. Batmaz ve L. Akhan Utaş, "Üniversite Öğrencilerinin Sağlıklı Yaşam Biçimi Davranışları", Maltepe Üniversitesi Hemşirelik Bilim ve Sanatı Dergisi, 3(3), 34-44, 2010. 